\title{
COMPARATIVE STUDY OF ERP IMPLEMENTATION METHODOLOGY CASE STUDY: ACCELERATED SAP VS DANTES \& HASIBUAN METHODOLOGY
}

\author{
M. Hilman, F. Setiadi, I. Sarika, J. Budiasto, and R. Alfian \\ Faculty of Computer Science, Universitas Indonesia, Kampus Baru UI Depok 16424 \\ Email: h.hilman@cs.ui.ac.id
}

\begin{abstract}
Enterprise Resource Planning (ERP) system is a concept of enterprise system that describe the integration of the whole process in the organization. Study in this field mostly about external development paradigm on information system development. So, issue in ERP is all about how to adopt it in the organization, not about the application development. This paper reviews two methodology on ERP system implementation, one is vendor perspective methodology and the other one is new generic perspective methodology. Comparation of both methodology is done in this study by using Roger Sessions' metric. Result is the vendor perspective slightly superior than the new generic perspective methodology.
\end{abstract}

Keyword: ERP, external development, methodology comparison.

\begin{abstract}
Abstrak
Sistem Enterprise Resource Planning (ERP) adalah sebuah konsep dari sebuah sistem yang menggambarkan integrasi dari seluruh proses dalam organisasi. Kajian di bidang ini mayoritas mengenai paradigma external development dalam pengembangan sistem Informasi. Dengan demikian, issue dalam ERP adalah tentang bagaimana cara untuk mengadopsi sistem ke dalam sebuah organisasi dan bukan tentang pengembangan aplikasi. Tulisan ini menelaah dua metodologi dalam implementasi/adopsi sistem ERP, yang pertama adalah metodologi dari perspektif vendor dan yang kedua adalah metodologi baru yang lebih generic. Perbandingan dari kedua metodologi yang dilakukan dalam penelitian ini menggunakan matrik yang dikenalkan oleh Roger Sessions. Hasilnya, perspektif vendor sedikit lebih unggul daripada metodologi dengan perspektif baru yang bersifat generic.
\end{abstract}

Kata Kunci: ERP, external development, perbandingan metodologi.

\section{Introduction}

Enterprise resource planning (ERP) system is an evolved information system technology. Leon describes it as "techniques and concepts for integrated management of bussines as a whole from the viewpoint of the effective use of management resources to improve the efficiency of enterprise management" [1]. Issues on ERP system are related to the external development paradigm. The main issue on implementing ERP is not (about) developing application to fulfill some certain objectives, but the feasibility to implement the integrated application that cover the whole organizational bussines process as one window system.

Many vendors has been researching and developing ERP system based on bussines best practices. The most popular vendors are SAP, Peoplesoft, JDEdwards, Oracle, and Baan. They already developed ERP system that represented major bussines process in the world. Vendor's packages is far to be compared with ERP in house development, or probably, just a few organization did that in their environment. Time deliverable and supporting service after going live, probably are the main reason why many organization decided to adopt the ERP system as an external development rather than developing in house application.

So then, the main issue on this external development paradigm is not about building the packages, but it refers to adopting it into the organization. Is there any correlation between the adoption methodology and the success of ERP system implementation? Dantes \& Hasibuan has proved [2] that the success story must've been supported by certain implementation methodology. Different way on implementing ERP system must have different effects to the 
organization. Some vendors surely have provided the customers with certain methodology that mostly suitable for their products, but there is also generic methodology, non-vendor perspectives, which can be implemented with any products of ERP system.

This paper is discussing ERP implementation methodology or kind of framework on adoption ERP system to the organization. Framework itself can be defined as "A structure for supporting or enclosing something else, especially a skeletal support used as the basis for something being constructed; An external work platform; a scaffold; A fundamental structure, as for a written work; A set of assumptions, concepts, values, and practices that constitutes a way of viewing reality" [3]. The paper contains a review of two different perspectives, one is vendor perspective and the other is generic perspective. We are comparing two ERP implementation methodology with certain metrics measurements and see how is the different between vendor provided methodology and generic methodology.

\section{ERP Implementation Methodology}

ERP implementation methodology have similar factors with software development life cycle or framework on developing software. However, the main difference is, in the ERP implementation methodology, we do not talk about how to develop ERP system. We are mainly discussing how the way to adopt ERP system with the organization. Rather then collecting requirements to build the suitable application, main activity when implementing ERP system is matching the organizational bussines process with the ERP system bussines process.

Here, we discuss two different perspective of ERP implementation methodology. One is vendor perspective methodology represented by Accelerated SAP [4], another one is generic methodology represented by Multi-factor Enterprise System methodology that published by Dantes \& Hasibuan [5].

\section{Methodology Assesment}

This paper used the metrics measurements that has been used with sessions from www.objectwatch.com on comparing four enterprise architecture methodologies [6]. Sessions provide 12 criterias with 4 ratings in each criteria. The ratings are very poor (1), inadequate (2), acceptable (3), and very good (4). There is no exact standar on giving some ratings in each criteria, sessions has warned about it in his whitepapers, but he gives practical example on giving the rate for each criteria.

Sessions criteria is quite relevant being easy way to choose whether the organization have to adopt complete ERP system, or just having several implemented (from one vendors), or combined packages from more than one vendors as the result from the evaluation. In this paper, the 12 citeria used (just) to assess new ERP implementation methodology with existed vendor perspective one by criterias as follows:

a. Taxonomy completeness refers to how well users can use the methodology to classify the various architectural artifacts.

b. Process completeness refers to how fully the methodology guides users through a step-bystep process for creating an enterprise architecture.

c. Reference-model guidance refers to how useful the methodology is in helping users build a relevant set of reference models.

d. Practice guidance refers to how much the methodology helps users assimilate the mindset of enterprise architecture into your organization and develop a culture in which it is valued and used.

e. Maturity model refers to how much guidance the methodology gives users in assessing the effectiveness and maturity of different organizations within your enterprise in using enterprise architecture.

f. Business focus refers to whether the methodology will focus on using technology to drive business value, in which business value is specifically defined as either reduced expenses and/or increased income.

g. Governance guidance refers to how much help the methodology will be in understanding and creating an effective governance model for enterprise architecture.

h. Partitioning guidance refers to how well the methodology will guide users into effective autonomous partitions of the enterprise, which is an important approach to managing complexity.

i. Prescriptive catalog refers to how well the methodology guides users in setting up a catalogue of architectural assets that can be reused in future activities.

j. Vendor neutrality refers to how likely users are to get locked-in to a specific consulting organization by adopting this methodology.

$\mathrm{k}$. Information availability refers to the amount and quality of free or inexpensive information about this methodology.

1. Time to value refers to the length of time users will likely be using this methodology 
before you start using it to build solutions that deliver high business value.

\section{Accelerated SAP}

Accelerated SAP (ASAP) is the vendor perspective methodology on implementing ERP system that released by SAP. ASAP provide step by step guidance on implementing SAP on the company. One of the main point from the ASAP, bussines process re-engineering is the best practice on adopting SAP into the company [7]. Doane show the reducing cost on SAP implementation that have been guided by the ASAP.

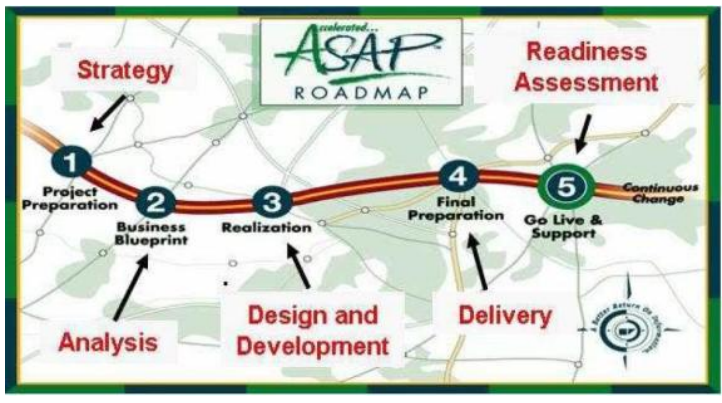

Fig 1. Accelerated SAP roadmap [8]

ASAP roadmap has been conducted by many SAP consulting firms in the world. The phases of ASAP (can be seen on the figure 1) are divided into 5 , here is the explanation of the phases with direct quotation with some additional explanation from [4] and [9]:

\section{a. Project Preparation}

Phase 1 initiates with a retrieval of information and resources. During this phase the team goes through initial planning and preparation for SAP project. The subphases on this phase are as follows:

i. Milestone.

ii. Project objectives.

iii. Decision-making process.

iv. Environment suitable for change and reengineering.

v. Building a qualified project team.

b. Bussines Blueprint

The purpose of this phase is to achieve a common understanding of how the company intends to run SAP to support their business. Also, to refine the original project goals and objectives and revise the overall project schedule in this phase. The result is the Business Blueprint, a detailed documentation of the results gathered during requirements workshops.

\section{c. Realization}

The purpose of this phase is to implement all the business process requirements based on the Business Blueprint. The realization phase can be divided into 2 as follows:

i. Configuration testing.

ii. Knowledge transfer.

d. Final Preparation

The purpose of this phase is to complete the final preparation. Workload testing and integration are conducted to ensure the accuracy of the data and the stability of SAP system.

e. Go Live \& Support

The purpose of this phase is to move from a project-oriented, pre-production environment to live production operation. The most important elements include setting up production support, monitoring system transactions, and optimizing overall system performance.

\section{Dantes \& Hasibuan Methodology}

Dantes \& Hasibuan began their research on ERP by finding key success factors (KSFs) on ERP implementation [2]. Then, they held quantitative experiment by observing some company in Indonesia related to their ERP implementation on their companies [10][11][12]. Many findings that been useful for constructing new methodology on implementing ERP system especially in Indonesia.

The proposed of new methodology begin with publication of [13] and [14]. The last publication [5] accepted in the society on 2011. Basically, this new methodology has not been widely used by the professional, but evaluation procedures can be done due to the complete documentation and characteristics as an ERP implementation methodology.

Based on the schema on figure 2, Dantes \& Hasibuan methodology focused on 5 aspects that become the subject of ERP implementation system. The 5 aspects are organization \& people, process, application, data, and infrastructure. While the phases that construct the whole methodology are divided into 5:

\section{a. Project Preparation}

Initial state of ERP implementation is assessing maturity level of an organization. They have been researching that there is correlation between ERP implementation success with the organizational maturity level. This activity is the unique process of Dantes \& Hasibuan methodology, another activity probably have the same activity with another implementation methodology. 


\section{b. Technology Selection}

This phase mainly consist of the procedure of building the project team that will handle the adoption project of ERP system. This part are dominated by determining the conceptual stage especially defining IS/IT strategy related to the ERP system that will be adopted.

\section{c. Project Formulation}

Formulation phase begin with the status analysis of legacy system and begin on collecting requirements needed by the company. The whole identification and collection are done in this phase.

d. Implementation \& Development

This part is the process of ERP system customization, to make sure it's alligned with the organization bussiness process. Included procedure are user training and system monitoring to see the system stability after migration.

\section{e. Post Implementation}

Came to this phase, the whole adoption process are completed. The remaining step is getting decision from the top company decision maker to make the system going live.

\section{Head to Head ASAP vs Dantes \& Hasibuan Methodology}

Review on two methodologies above is complete enough to explain the detail of each methodology. However, to give holistic view on comparison methodology, that is not enough. This part visualizes the similarity and difference between two methodologies in the way that can be easily understood. That visualization can be seen in Table I. Then, the sessions' performance matrices that applied to both methodologies can be seen in the Table II - XIII.

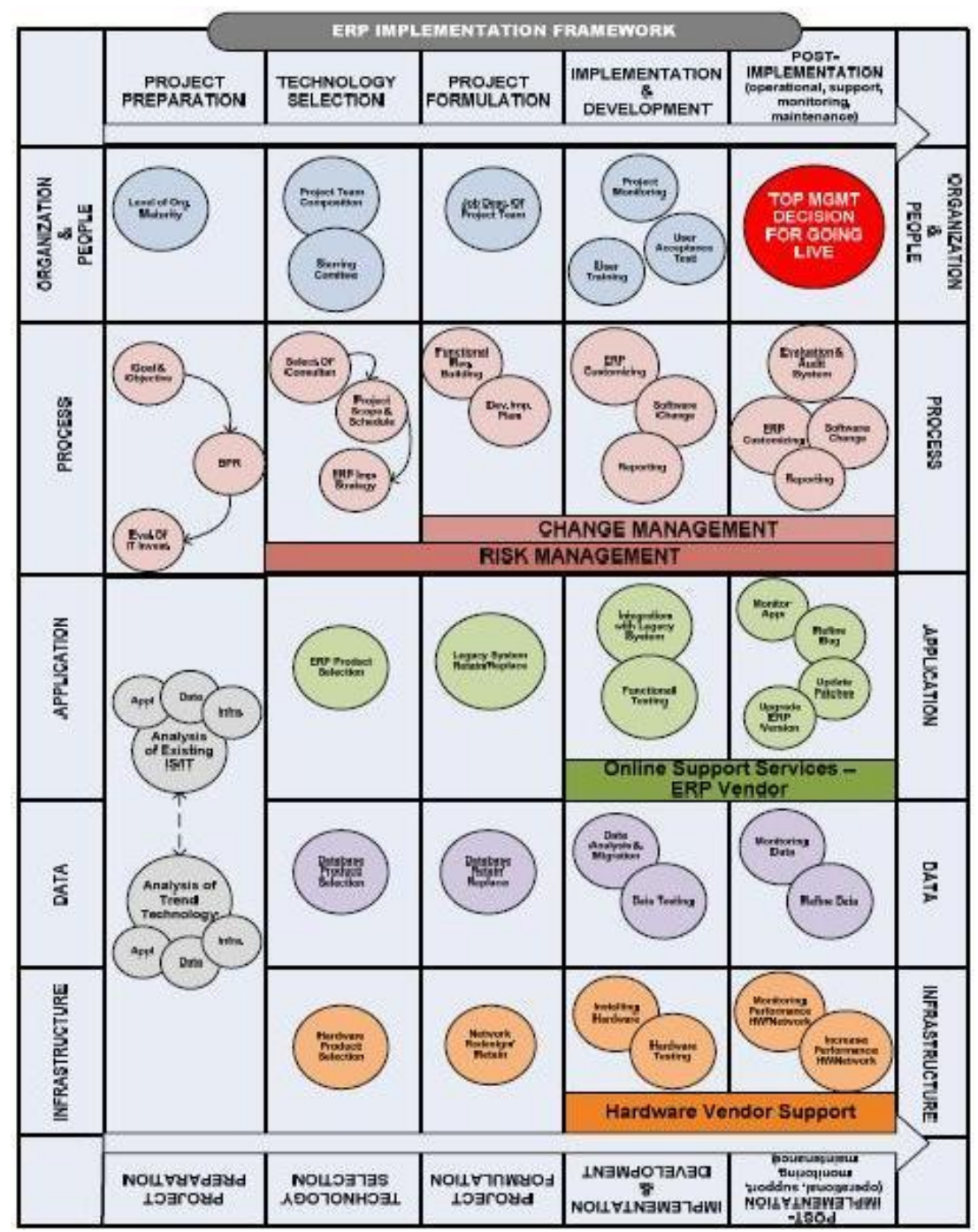

Fig 2. Dantes \& Hasibuan ERP implementation methodology [5] 
12 Journal of Information Systems, Volume 8, Issue 1, April 2012

TABLE I

COMPARISON OF ACCELERATED SAP VS. DANTES \& HASIBUAN METHODOLOGY ON STRUCTURAL FRAMEWORK

\begin{tabular}{|c|c|}
\hline Accelerated SAP & Dantes \& Hasibuan Methodology \\
\hline Project Preparation & Project Preparation \\
\hline $\begin{array}{l}\text { - Initial project planning, scoping and goal setting } \\
\text { - } \quad \text { Implementation strategy } \\
\text { - Implementation sequence } \\
\text { - } \quad \text { Team formation } \\
\text { Project kick off }\end{array}$ & $\begin{array}{l}\text { - } \text { Identification of organization maturity level } \\
\text { - } \quad \text { Befine clear goal \& objective } \\
\text { - } \text { Evaluation of IT } \\
\text { - Analysis of existing IS/IT } \\
\text { - Analysis of trend technology }\end{array}$ \\
\hline Business Blueprint & Technology Selection \\
\hline $\begin{array}{l}\text { - } \text { Refining goals and objectives } \\
\text { - } \text { Requirement gathering } \\
\text { - } \text { As-Is and To-Be documentation } \\
\text { - }\end{array}$ & 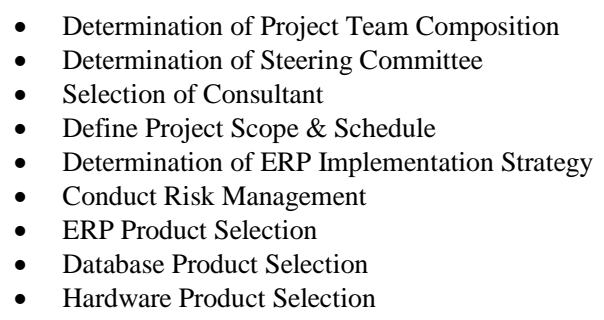 \\
\hline Realization & Project Formulation \\
\hline 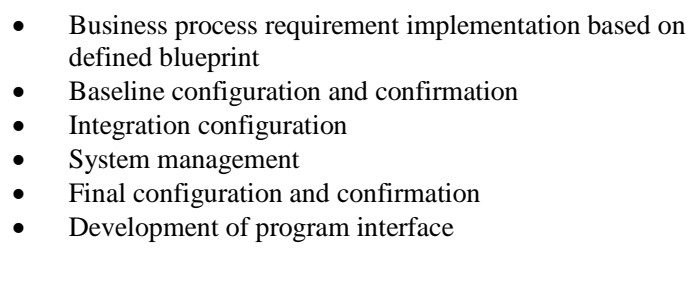 & $\begin{array}{l}\text { - } \text { Define Job Description of Project Team } \\
\text { - } \quad \text { Functional Requirement Building } \\
\text { - } \quad \text { Conduct Change Management } \\
\text { - Identification of Legacy System } \\
\text { (Retain/Replace)Identification of Database } \\
\text { - } \quad \text { (Retain/Replace) } \\
\text { Identification of Networks (Redesign/Replace) }\end{array}$ \\
\hline Final Preparation & Implementation \& Development \\
\hline $\begin{array}{ll}\text { - } & \text { Unit testing } \\
\text { - } & \text { Integration testing } \\
\text { - } & \text { Syser training } \\
\text { - } & \text { Cutover management }\end{array}$ & $\begin{array}{l}\text { - } \text { Project Monitoring } \\
\text { - } \text { User Acceptance Test } \\
\text { - } \text { User Training } \\
\text { - } \text { Software Change } \\
\text { - } \text { Reporting } \\
\text { - } \text { Integration with Legacy System } \\
\text { - } \text { Hunctional Testing } \\
\text { - } \text { Datine Support Service with ERP Vendor } \\
\text { - } \text { Data Testing } ~ \\
\text { - Hardware Installation } \\
\text { - Hardware Testing } \\
\text { Hardware Vendor Support }\end{array}$ \\
\hline
\end{tabular}

\begin{tabular}{ll}
\multicolumn{1}{c}{ Go-Live \& Support } & \multicolumn{1}{c}{ Post-Implementation } \\
\hline - Migration to production environment & - Top Management Decision for Go Live \\
- Support & - Evaluation \& Audit System \\
- Perforing & - Ronitoring Application \\
& - Update Patches (if any) \\
& - Mpgrade ERP Version (optional) \\
& - Ronitoring Database \\
& - Monitoring Performance Hardware \& Network \\
&
\end{tabular}


TABLE II

SESSION'S PERFORMANCE METRICS ON TAXONOMY COMPLETENESS

\begin{tabular}{lcc}
\hline Criteria & Accelerated SAP & $\begin{array}{c}\text { Dantes \& } \\
\text { Hasibuan } \\
\text { Methodology }\end{array}$ \\
\hline $\begin{array}{l}\text { Taxonomy } \\
\text { completeness }\end{array}$ & 1 & 4 \\
\hline
\end{tabular}

The explanation for Table II is as follows: based on American Heritage Dictionary, Taxonomy: "The classification of organisms in an ordered system that indicates natural relationships; the science, laws, or principles of classification; systematic; Division into ordered groups or categories" [15]. So, taxonomy is another term for classification or categorization. Dantes \& Hasibuan methodology classify focus area into five aspects (1) organization \& people, (2) process, (3) application, (4) data, and (5) infrastructure meanwhile ASAP didn't explain focus area in direct way.

TABLE III

SESSION'S PERFORMANCE METRICS ON PROCESS COMPLETENESS

\begin{tabular}{lcc}
\multicolumn{2}{c}{ COMPLETENESS } \\
\hline Criteria & Accelerated SAP & $\begin{array}{c}\text { Dantes \& } \\
\text { Hasibuan } \\
\text { Methodology }\end{array}$ \\
\hline $\begin{array}{l}\text { Process } \\
\text { completeness }\end{array}$ & 4 & 3 \\
\hline
\end{tabular}

The explanation for Table III is as follows: process completeness refers to how methodology guides the process through procedures (in this case process on implementing ERP). Both methodologies have similar general procedures ( 5 procedures). Both are having systematic and holistic procedures from preparation until postimplementation but Dantes \& Hasibuan methodology make redundant procedures, for example in the fourth and fifth stage, each stage repeated the same procedures which are ERP customizing, software changes, and reporting. The redundant procedure in a certain methodology probably will make some ambiguity and impressed (on a negative way) some kind of inefficiency.
TABLE IV

SESSION'S PERFORMANCE METRICS ON REFERENCE-MODEL

\begin{tabular}{ccc}
\hline Criteria & Accelerated SAP & $\begin{array}{c}\text { Danes \& Hasibuan } \\
\text { Methodology }\end{array}$ \\
\hline Reference-model & 1 & 1 \\
\hline
\end{tabular}

The explanation for Table IV is as follows: both methodologies don't help users for defining reference-model. So, both of them given low rate on these particular aspects.

TABLE V

SESSION'S PERFORMANCE METRICS ON PRACTICE GUIDANCE

\begin{tabular}{lcc}
\hline Criteria & Accelerated SAP & $\begin{array}{c}\text { Dantes \& Hasibuan } \\
\text { Methodology }\end{array}$ \\
\hline $\begin{array}{l}\text { Practice } \\
\text { guidance }\end{array}$ & 4 & 3 \\
\hline
\end{tabular}

The explanation for Table $\mathrm{V}$ is as follows: practice guidance is a criterion that gives some guidance based on practical approach. Dantes \& Hasibuan methodology designing framework based on KSFs criteria which proved from their research and observation on Indonesia's companies while ASAP designing framework based on best practice many SAP users. This ASAP is more robust and evolving every time. So, ASAP got more ratings on this aspect.

TABLE VI

SESSION'S PERFORMANCE METRICS ON MATURITY MODEL

\begin{tabular}{ccc}
\hline Criteria & Accelerated SAP & $\begin{array}{c}\text { Dantes \& Hasibuan } \\
\text { Methodology }\end{array}$ \\
\hline Maturity model & 2 & 4 \\
\hline
\end{tabular}

The explanation for Table VI is as follows: Dantes \& Hasibuan begin their framework with possibility to assess the maturity level of the organization. While ASAP doesn't seems provide some facility or indicators to do so in the beginning level of ERP system implementation.

TABLE VII

SESSION'S PERFORMANCE METRICS ON BUSINESS FOCUS

\begin{tabular}{ccc}
\hline Criteria & Accelerated SAP & $\begin{array}{c}\text { Dantes \& Hasibuan } \\
\text { Methodology }\end{array}$ \\
\hline Business focus & 4 & 2 \\
\hline
\end{tabular}


The explanation for Table VII is as follows: ASAP has been proved on reducing the cost based on the technology used (SAP). Doane in [7] shown the table contains some reducing cost calculation on it while Dantes \& Hasibuan hasn't been proved on reducing cost and drives business with ERP system.

TABLE VIII

SESSION'S PERFORMANCE METRICS ON GOVERNANCE GUIDANCE

\begin{tabular}{lcc}
\multicolumn{3}{c}{ GUIDANCE } \\
\hline Criteria & Accelerated SAP & $\begin{array}{c}\text { Dantes \& Hasibuan } \\
\text { Methodology }\end{array}$ \\
\hline $\begin{array}{l}\text { Governance } \\
\text { guidance }\end{array}$ & 2 & 2 \\
\hline
\end{tabular}

The explanation for Table VIII is as follows: Governance guidance including 3 main aspects: Business, Process and IT. Besides, there are level, priority, and clear job description with certain indicators on each aspect. ASAP will provide more efficiency on management. Unfortunately, both of methodology doesn't have specific job description especially in the process part.

TABLE IX

SESSION'S PERFORMANCE METRICS ON PARTITIONING GUIDANCE

\begin{tabular}{lcc}
\hline Criteria & Accelerated SAP & $\begin{array}{c}\text { Dantes \& Hasibuan } \\
\text { Methodology }\end{array}$ \\
\hline $\begin{array}{l}\text { Partitioning } \\
\text { guidance }\end{array}$ & 4 & 2 \\
\hline
\end{tabular}

The explanation for Table IX is as follows: partitioning workload on ASAP is perfect. They give automatic generator workload on their framework. Besides, another material and contents that probably needed by users are available on their websites. In this phase, Dantes \& Hasibuan methodology doesn't have quite power to compete.

TABLE X

SESSION'S PERFORMANCE METRICS ON PRESCRIPTIVE CATALOG

\begin{tabular}{lcc}
\hline Criteria & Accelerated SAP & $\begin{array}{c}\text { Dantes \& Hasibuan } \\
\text { Methodology }\end{array}$ \\
\hline $\begin{array}{l}\text { Prescriptive } \\
\text { catalog }\end{array}$ & 4 & 3 \\
\hline
\end{tabular}

The explanation for Table $\mathrm{X}$ is as follows: ASAP describe their main phase (preparation, business blueprint, realization, final preparation, and go live) into structured sub phases. So that's why, it will help users and guide them descriptively on implementing ERP system. Dantes \& Hasibuan methodology have the same good prescriptive catalog but it seems put too much explanation.

TABLE XI

SESSION'S PERFORMANCE METRICS ON VENDOR NEUTRALITY

\begin{tabular}{lcc}
\hline Criteria & Accelerated SAP & $\begin{array}{c}\text { Dantes \& Hasibuan } \\
\text { Methodology }\end{array}$ \\
\hline $\begin{array}{l}\text { Vendor } \\
\text { neutrality }\end{array}$ & 1 & 4 \\
\hline
\end{tabular}

The explanation for Table XI is as follows: it's quite clear that ASAP doesn't represent vendor neutrality because this framework is designed based on SAP implementation while the generic one will have more ratings on this aspect.

TABLE XII

SESSION'S PERFORMANCE METRICS ON INFORMATION AVAILABILITY

\begin{tabular}{lcc}
\hline Criteria & Accelerated SAP & $\begin{array}{c}\text { Dantes \& Hasibuan } \\
\text { Methodology }\end{array}$ \\
\hline $\begin{array}{l}\text { Information } \\
\text { availability }\end{array}$ & 3 & 1 \\
\hline
\end{tabular}

The explanation for Table XII is as follows: ASAP provide more additional information on their websites to help users on implementing SAP in their organization. Dantes \& Hasibuan hasn't provide yet additional information beside their technical information on the paper.

TABLE XIII

SESSION'S PERFORMANCE METRICS ON TIME TO VALUE

\begin{tabular}{ccc}
\hline Criteria & Accelerated SAP & $\begin{array}{c}\text { Dantes \& Hasibuan } \\
\text { Methodology }\end{array}$ \\
\hline Time to value & 4 & 3 \\
\hline
\end{tabular}

The explanation for Table XIII is as follows: both ASAP and Dantes \& Hasibuan methodology has shown in their reports that implementation process of ERP is in range of $8-10$ months. But, Dantes \& Hasibuan methodology give its basis on research (before time), while ASAP based on 
experience. The total score for ASAP based on the sessions' performance matrix is 34 while the score for Dantes \& Hasibuan methodology is 32 .

\section{Conclusion}

So, the conclusion in this comparative study is the ASAP has slightly superior than Dantes \& Hasibuan methodology. There are some aspects of metrics especially, taxonomy, maturity model, and vendor neutrality that ASAP is inferior compared to Dantes \& Hasibuan methodology. However, ASAP is evolving and widely used by many organization in the world. Dantes \& Hasibuan methodology has very good theoritical background and research as if it is rated quite good, just slightly inferior than ASAP. More evolving this framework, and more wide its usage, the new generic framework will grown into robust ERP system implementation methodology.

\section{References}

[1] Leon, A., Enterprise Resource Planning, McGraw Hill Education, September 2007.

[2] Dantes, G.R., Hasibuan, Z.A., "Measurements of Key Success Factors (KSFs) on Enterprise Resource Planning (ERP) Adoption", IBIMA Business Review Journal, 2010.

[3] "Framework", The American Heritage Dictionary of the English Language, Fourth Edition, Boston, MA: Houghton Mifflin Company, 2006.

[4] Anderson, G., Larocca, D., Sams Teach Yourself $S A P^{T M}$ in 24 Hour, Second Edition, 2005.

[5] Dantes, G.R., Hasibuan, Z.A., "Enterprise Resource Planning Implementation Framework Based on Key Success Factors (KSFs)", UK Academy for Information System, Oxford, UK, 2011.
[6] Sessions, R., "Comparison of the top four enterprise architecture methodologies", Technical Report, May 2007.

[7] Doane, M., The New SAP Blue Book, 2007.

[8] Accelerated SAP roadmap picture, available online on http://www.iwi.unihannover.de/upload/lv/sosem08/seminar/w ww/buehrig_Grafiken/asap.jpg accessed on October 25,2011.

[9] Eseyin, K., "A Concise Overview of Accelerated SAP (ASAP) Methodology", available online on http://it.toolbox.com/blogs/sap-library/aconcise-overview-of-accelerated-sap-asapmethodology-32964 accesses on October 25, 2011.

[10] Dantes, G.R., Hasibuan, Z.A., "Enterprise Resource Planning (ERP) Implementation: Any Competitive Advantage for the Company", in Proceeding IADIS International Conference, Avila, Spain.

[11] Dantes, G.R., Hasibuan, Z.A., "The Impact of Enterprise Resource Planning (ERP) Implementation", IBIMA Bussines Review Journal, 2011.

[12] Dantes, G.R., Hasibuan, Z.A., "Comparison of ERP Implementation Process of Two Organizations: an Exploratory Research", in Proceeding ICSSH, Singapore, 2011.

[13] Dantes, G.R., Hasibuan, Z.A., "ERP Implementation Methodology: a Preliminary Design", in Proceeding ICCCIT, Jakarta, 2009.

[14] Dantes, G.R., Hasibuan, Z.A., "Step-Wise Approach Toward ERP Implementation Success", in Proceeding International Conference IBIMA $16^{\text {th }}$, Kuala Lumpur, 2011.

[15] "Taxonomy". The American Heritage Dictionary of the English Language, Fourth Edition, Boston, MA: Houghton Mifflin Company, 2006. 